\title{
US government asked to fund more industrial research
}

Washington. In a move certain to fuel the debate over industrial policy, the US $\mathrm{Na}$ tional Science Board released a report* last week that laments the amount of US industrial research and calls for increased federal

\section{Hard times for industrial R\&D}

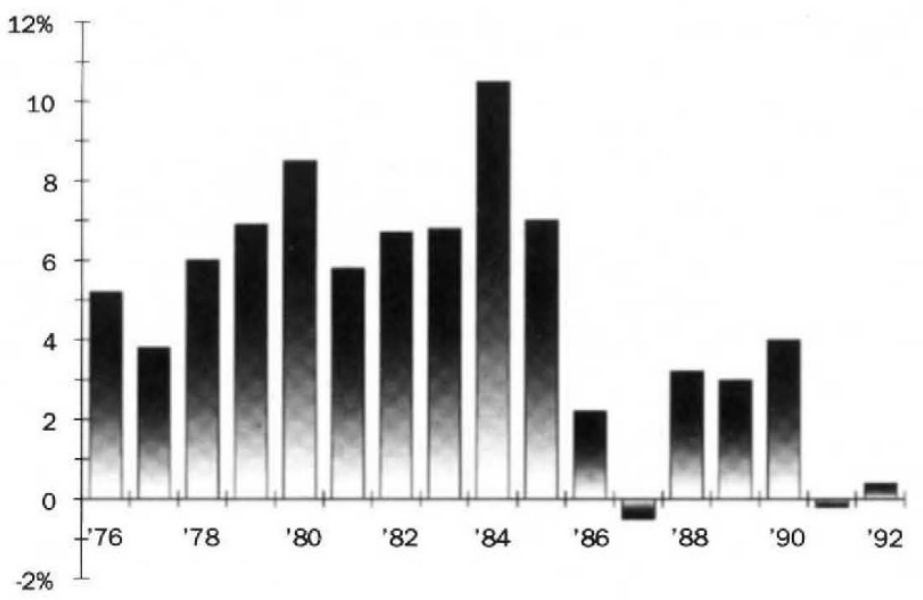

(Annual growth in constant dollars)

support of industry. Citing a number of recent studies and some previously unpublished surveys that show a stagnation in US industrial research spending relative to gross domestic product (GDP), the board recommends that the government "re-examine [its] traditional isolation from business issues" and increase its support of programmes that directly help industrial product development and manufacturing.

The board, the policy arm of the National Science Foundation, did not actually use the words "industrial policy", a term that is still anathema to the administration. But it clearly endorsed the concept. It recommends that the government reorientate its research and development (R\&D) budgets away from defence missions and towards the needs of industry. And it calls on federal science agencies to give greater consideration in awarding grants to US industrial competitiveness or technologies in which the United States is slipping.

The board calculated that the United States would now have to increase its $\mathrm{R} \& \mathrm{D}$ spending by $\$ 25$ billion (about 16 per cent beyond current levels) to match Japan, the world's leader in industrial $R \& D$ spending relative to GDP. It blames the gap on a preoccupation within industry on short-term investment and corporate restructuring. But it also calls on Congress and the administration to make it easier for industry to increase its domestic research spending by making permanent a now-temporary R\&D tax credit and by removing a portion of the tax code that encourages US companies to move their R\&D to foreign countries to receive a tax break on overseas sales.

Christopher Anderson

* The Competitive Strength of US Industrial Science and Technology: Strategic Issues; National Science Board, 1992

\section{Government spending on R\&D (1989 percentage)}

\section{Defence}

Civil space

Advancement of research

Health

Industrial

development

$$
\text { US }
$$

$$
7.3
$$

$$
3.9
$$

Agriculture, forestry and fisheries
Energy
$4.5 \quad 7.6$

\begin{tabular}{crr} 
Germany & France & UK \\
\hline 19.0 & 41.9 & 55.2 \\
8.5 & 8.7 & 3.8 \\
20.7 & 17.5 & 5.8
\end{tabular}

13.8

\author{
4.8
}

$$
5.2
$$

8.1

19.0

15.0

10.3

$$
\text { Other }
$$

\section{5}

4.0

6.5

$$
3.1
$$

4.6

5.5

$\begin{array}{lll}14.9 & 4.5 & 9.2\end{array}$

NEWS IN BRIEF

Washington. US legislators passed a bill last week that will explicitly define crimes committed at animal research facilities as federal offences. But because backers have been forced to weaken the bill considerably in their three-year struggle to pass such animal legislation, its effect will be mostly symbolic. It covers only crimes that are committed on an interstate basis and cause damage exceeding $\$ 10,000$ conditions that would make the crimes federal offences regardless of any special law. However, the bill extends federal law by including a provision requiring those found guilty to pay the cost of repeating disrupted experiments. It also requires a federal study on the effect of terrorism on animal facilities, which include agricultural enterprises as well as research institutions.

\section{C.A.}

Washington. An animal-rights magazine revealed last week that one of its own the US National Anti-Vivisection Society (NAVS) - held $\$ 88,000$ of stock in US Surgical, a medical supply company that has become one of the chief targets of animal activists. The Animals' Agenda reported in its July/August issue that NAVS also holds stock in Wal-Mart Stores, which have been boycotted by animal groups for selling live animals to "puppy mills". Mary Margaret Cunniff, the society's executive director, explains that the US Surgical stocks were purchased last year without the organization's knowledge by a money manager, and that NAVS divested itself of the stock earlier this year when it discovered the mistake. "Of all the companies [the manager] could have purchased, US Surgical was the worst", she says. NAVS received a $\$ 2$-million bequest several years ago and now uses independent consultants to manage its financial policy to decide how to bring its investments in line with its ethics.

Washington. A bill to create a science foundation to promote research in former Soviet states has passed both houses of Congress and needs only a budget before it can be put in place. Its sponsors have requested $\$ 25$ million, but its fate is tied to the resolution of the 1993 defence appropriations bill, from which the foundation would be funded. The bill, a brainchild of Representative George Brown (Democrat, California), directs the National Science Foundation (NSF) to establish a non-profit, non-government foundation to foster basic research and technology transfer in the former Soviet states (see Nature 355,$576 ; 1992)$. The NSF is expected to model the foundation after a similar US-funded organization in Israel supporting Israeli science. Once funded, the new foundation is expected to award money to US-Soviet research teams on the basis of peer-reviewed grant applications and to encourage the states' academic scientists to collaborate with industry on non-defence research and development 